\title{
Complex interactions envolving a gall midge Myrciamyia maricaensis Maia (Diptera, Cecidomyiidae), phytophagous modifiers and parasitoids
}

\author{
Fernando Fortunato Faria Ferraz \& Ricardo Ferreira Monteiro
}

Laboratório de Ecologia de Insetos, Departamento de Ecologia, Instituto de Biologia, Universidade Federal do Rio de Janeiro. Caixa Postal 68020, Ilha do Fundão, 21941-590 Rio de Janeiro, Rio de Janeiro, Brasil. E-mail: ferrazfff@ig.com.br; monteiro@biologia.ufrj.br

\begin{abstract}
Myrciamyia maricaensis Maia, 1995 (Diptera, Cecidomyiidae) induces a gall in lateral and apical shoots in the plant Myrcia lundiana Kiaersk (Myrtaceae) which is used and modified by two eulophid wasps species. In both cases the gall former species suffer high rate of attack exceeding the importance of parasitoid species as mortality factors. In this study these interactions are described and their effects as mortality of gall former. The intensity of occurrence of the two eulophid species as modifiers and of microhymenopteran parasitoids, and the relative importance of these species as mortality agents of the M. maricaensis larvae is compared. This comparison reveals that two modifiers species found in the gall tissue modification causing the death of the M. maricaensis larva and it is a more important factor of mortality than the cecidomyiid larva parasitism. The fluctuation of the number of each type of gall along the year was monitored in the research field and confirmed in numerical and in synchronic terms of occurrence of the galls; the importance of the species of the gall modifier eulophids, particularly one of these species, as factors of mortality of the M. maricaensis larvae and justified our comparing the relationship between these species and M. maricaensis as similar to the parasitoid-host relationship. The gall shape modification by one of the eulophids allows the occurrence of other inquiline insect species, what means that this gall modification becomes it more heterogeneous and allows the increase of the species richness to the system.
\end{abstract}

KEY WORDS. Brazil, endogall, fluctuation population, Restinga.

The collection of non cecidogenous microhymenopterous from galls has been frequently registered in the literature (WASHBURN \& Cornell 1981, Hawkins \& Goeden 1984, Hawkins \& GaGné 1989, BRIGgS \& LATTO 1996). These interactions are mostly parasitical and frequently cause high mortality rates to the host galler larvae (Weis \& Abrahamson 1985, Price \& Clancy 1986).

Nevertheless, the great majority of the microhymenopterous associated with the galls are parasitoid, many phytophagous species are also found among them.

The phytophagy, including the cecidogenesis, was many times developed in the Chalcidoidea and can be found in the Agaonidae, Eurytomidae, Pteromalidae, Tanaostigmatidae, Torymidae, Eupelmidae e Eulophidae families (GAHAN 1922, GAHAN \& FERRIÈRE 1947). The phytophagy, however, is relatively rare in the Eulophidae family, being known just a few phytophagous eulophids, especially among the tetrastichines, which are in their majority, gall inquilines and just a few gallers or seed predators (LaSALLE \& SCHaufF 1995).

Among the microhymenopteran gallers, Hawkins \& GoEDEN (1982) detailed the biology of the Tetrastichus cecidobroter
Gordh \& Hawkins, 1982 (Hymenoptera, Eulophidae) characterizing this species as a cecidogenous that induces galls in the tissue of another gall. T. cecidobroter oviposits in the Asphondylia atriplicis Cockerell gall tissue (Diptera, Cecidomyiidae) producing internal galls that cause a great modification of the original gall and causes the death of the galler larva through its chamber compression. These galls developed like this way were named endogalls (Hawkins \& GoEden 1982).

Tetrastichus cecidobroter and three torimid species mentioned by CURRIE (1937) are the only examples of endogallers known up to date, however, in the case of the torimids, the associations in Eucalyptus sp. are facultative. Only T. cecidobroter was described as an example of obligatory interaction between an hymenopteran and a dipterous, both gallers. In the interactions mentioned above, the cecidogenous larvae suffer mortality as a result of the gall tissue modification by the modifying species, but this characteristic is especially remarkable in the T. cecidobroter case.

In the present study the modifications in the shape of a shoot gall induced by the Myrciamyia maricaensis Maia 1995

Revista Brasileira de Zoologia 20 (3): 433-437, setembro 2003 
(Diptera, Cecidomyiidae) in the Myrcia lundiana Kiaersk. (Myrtaceae) caused by chalcidoid wasps is described. The trophic relationships in this gall, the intensity of the attack of the modifiers and parasitoid wasps and the relative importance of each one of them in this system were also investigated.

\section{MATERIAL AND METHODS}

Fieldwork was carried out at the restinga habitat of Barra de Maricá, a municipality of Maricá, in the state of Rio de Janeiro, Brazil. The study area is situated about $60 \mathrm{~km}$ away from Rio de Janeiro city and is characterized by its typical restinga shrub structure.

Between June 1991 and June 1992 seven plants were monthly inspected. From July 1992 until August 1993 monthly systematic examinations has started, monitoring an average number of 15 individuals of the host plant in two areas of that restinga where there is the plant incidence.

From this last date on, no other plant sample was collected but only registered the total number of galls in each plant besides the plant fenological state at each monthly examination. This procedure aimed at not interfering in the galler population fluctuation, once the host plant Myrcia lundiana, a small bush, is not abundant in the study area and is restricted to very few dispersed patches in the area. (Important note: Recently, the sample referent to M. maricaensis host plant cited in MaIA (1995) as Myrcia ovata, was re-examined and identified as Myrcia lundiana Kiaersk).

One of the commonest galls of M. lundiana had a very ridged surface. Inductors of this gall were obtained after several months of rearing in the laboratory. Adults and immatures of this species were then described by MAIA (1995) as Myrciamyia maricaensis. This gall produced by the $M$. maricaensis presents two other well defined shapes, distinct from the original one. Each type is the result of the occurrence of distinct microhymenopterous using the gall. Then it was possible to obtain the relative frequencies of these three insect species without collecting the galls.

A total number of 51 galls were collected in the months of June and July of 1991 and 38 galls in January and February of 1992 in order to evaluate of the content of each gall and determining the role of each species of insect present in the gall.

A part of the collected galls was dissected under a stereomicroscope for their internal morphology characterization and to observe the habits and interactions of the immature insects. Another part of the galls was separated in order to obtain the adult insects. The galls were individualized in plastic pots covered with moistened absorbent paper to increase the chances of the insect emergence.

During the period from February until July, 1992, only sporadic small samples up to 10 galls, of the three types were made to obtain the largest number of adult insects.

\section{RESULTS}

\section{Biology and Interspecific Interactions}

The M. maricaensis gall (Fig. 1) is about one centimeter in its largest length and contains only one larva occupying just a single chamber. The gall develops itself in the apical and lateral shoots of the branches but it also occurs, even though more rarely, in the inflorescences of the Myrcia lundiana. This one also presents a pointed apex that resembles a thorn and next to it, where the surface is smooth, a small tenuous circular line is formed delimiting the adult galler exit hole. The adult emergence occur through the pupa movement, bursting the exuvia and leaving it stuck to the outside of the gall opening.

The M. maricaensis gall develops quickly and presents a green or a white reddish coloration during the beginning of its development. When it is totally developed, it assumes a brown color, apparently as a result of its tissue drying up, still in the plant. After this process, it suffers abscission remaining under the host plant under the litter in the soil. Even though the emergence of inductors has been observed from some galls still in the host plant, the galler larva development generally completes itself when the gall is under the litter, where the adult galler then emerges.

Even though some adults may emerge a few days after this process, a great amount of dry galls, but containing living larvae inside themselves, may be found intact in the litter under the host plants some months after the end of the occurrence peak of the galls in the plants.

It was also checked out, in the laboratory, that not only the galls collected from the soil but also in the host plant, in general take some months until the cecidomyiid adult emerge. This suggests that, even though part of the adult insects emerge within a short span of time in the plant or after they fall on the soil, most of them posses diapause in the last larval instar.

The original cecidomyiid gall presents two types of changes in its original shape, both caused by the action of wasps, and also suffers the attack of a gregarious parasitoid species of the Platygasteridae family. The first species, of the Eulophidae family, gregarious, leaves the gall with a slightly bigger size, without the characteristic sections of the original M. maricaensis gall and does not cause any inner changes in the gall, leaving it with the only central cecidomyiid chamber intact (figure 1 - modified gall).

The second eulophid species, a Tetrastichini, oviposit in the small and young gall, which produces several endogalls (internal galls in the original gall tissue) that cause a deep change in the primitive shape of the gall. Each larva of this microhymenopteran induces a small spherical endogall in the M. maricaensis gall internal wall. With the development of the several endogalls of this eulophid galler, the original gall walls become thicker (hypertrophied). The final result of this process is the gall bigger than the original and the radical change in its internal and external shape, originating a gall with a roughly external globular shape and with its surface ranging from smooth to irregular and internally with a large number of small chambers of a compact and hard tissue (see figure 1 globular modified gall - endogall).

The development of the several endogalls inside the $M$. maricaensis gall causes a radical change in the original gall anatomy having as a result the compression and closing of the central chamber occupied by the M. maricaensis larva, just leaving, in the end of the development process of the endogalls, vestiges of the chamber occupied by the dipterous larva, totally closed by the wasps endogalls placed around it (figure 1 globular modified - longitudinal cut). As a result, we found out that these endogalls caused the cecidomyiid larvae death in almost all the modified galls observed in laboratory environment $(\mathrm{N}=72)$. In some cases the gall suffered minor changes 


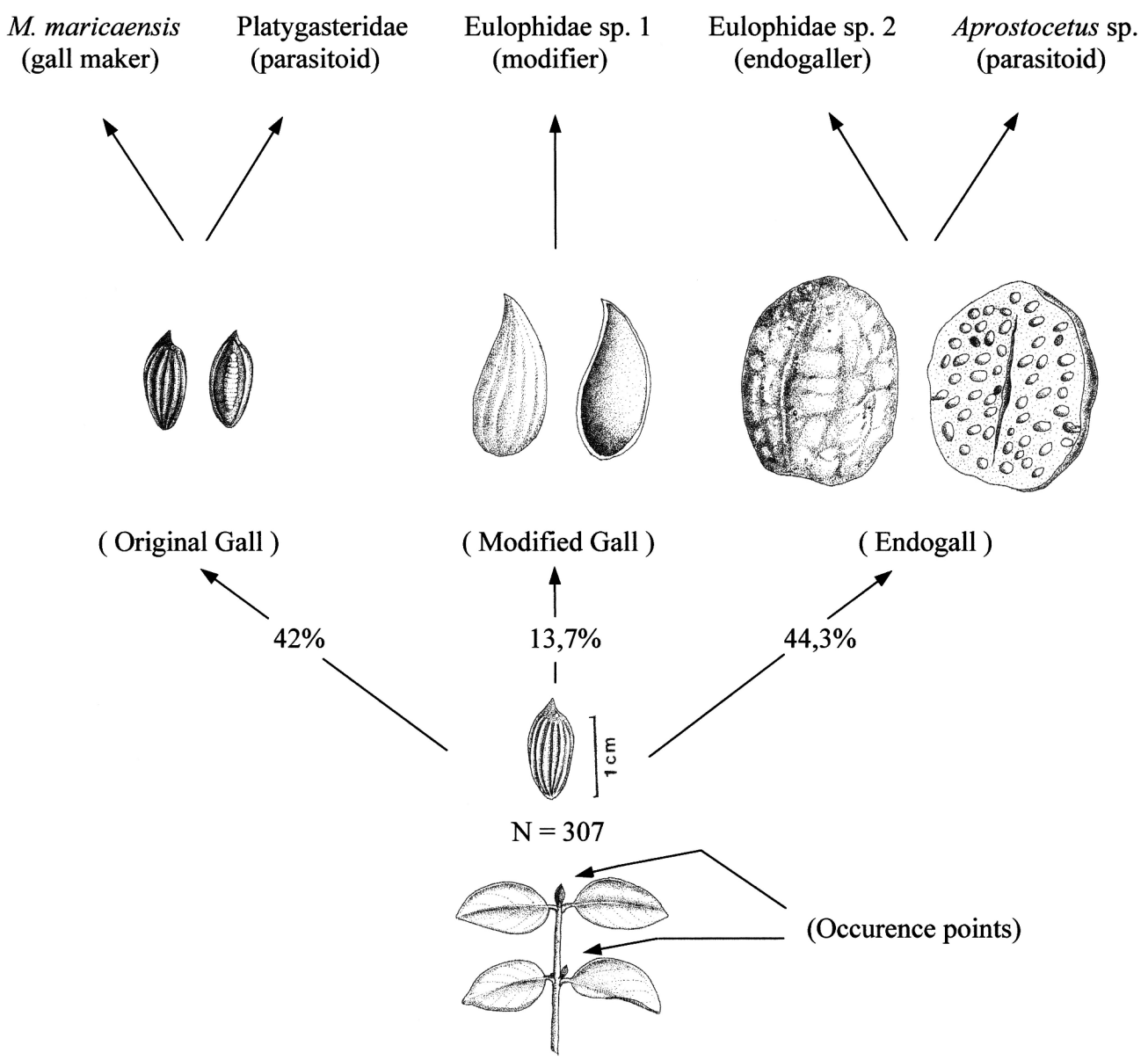

Figure 1. Ilustration showing the Myrciamyia maricaensis gall (original gall) and the two kinds of modifications of this gall (modified gall and globular gall - endogall) caused by the eulophid species. The proportions of occurrence of each type of gall are also shown.

having an intermediary appearance between the original gall and the globular gall. In these cases it was checked that there were few endogalls and as the cecidomyiid central chamber compression was smaller, the M. maricaensis larva still survived.

A number of up to 105 wasps per gall of this endogaller species was obtained but the average was of 23.1 individuals/ gall $(\mathrm{N}=25, \mathrm{SD}=29.7)$, and the sexual rate was of 2.5 females/ male $(\mathrm{N}=574)$.

Approximately $1 / 3$ of the globular galls obtained in the laboratory $(\mathrm{N}=25)$ was parasited by the Aprostocetus sp. (Eulophidae), however with low parasitism per parasited gall (ranging from $0.5 \%$ to the maximum of $35 \%$ of the parasited endogaller larvae/gall; $\mathrm{N}=304$ ).

The gall transformed by the eulophid sp.1 (modified) was scarcely abundant representing $13.7 \%$ of all the galls registered between 1992 and $1993(\mathrm{~N}=307)$ and occurred in a more restrict way along the year. The globular gall, however, was the most abundant one $(44,3 \%)$, surpassing the $M$. maricaensis original gall in numerical terms $(42,0 \%)$ (Fig. 1).

Three other phytofagous insect species larvae were also detected in the globular gall (endogall), a curculionid, a microlepidopteran and dipteran, scarcely abundant, whose larval phases use the gall tissue as its food. The first two species caused considerable damage to the gall, killing several eulophids endogaller larva species.

Besides the two species of eulophids that live in galls, $M$. maricaensis larvae were also attacked by a gregarious species of Platygasteridae, that were responsible for $8 \%$ of the gall parasitism, of a total number of 51 galls collected between the months of June/1991 and Ocotober/1992.

\section{Population Fluctuation}

The M. maricaensis original gall occurred along all the year being more frequent during the drought season between the months of April and July. This same temporal pattern is followed by the microhymenopteran endogaller, even though it was much less evident (Fig. 2).

The time of greater abundance of the M. maricaensis gall and of the modified galls coincides with the two phases of greater vegetative growth (foliar sprouting) and the flowering 
of the M. lundiana (Fig. 2). Nevertheless, the host plant produces new leaves (sprouting) during all the year, making the resources available (meristematic tissues) for the galler also along the whole year.

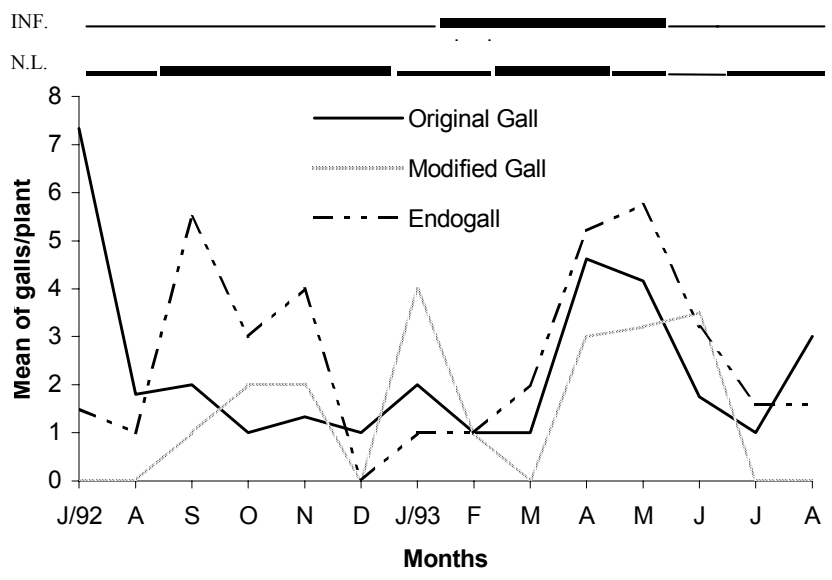

Figure 2. Population fluctuation of original, modified and globular (endogall) galls of M. maricaensis, during 1992 and 1993. On the top part of the figure the diagram shows the relative frequency of plants with inflorescence and with new leaves. (INF.) Inflorescence, (N.L.) New Leaves, (-) 0-40\%, (-) 41-70\%, (-) above 70\%.

\section{DISCUSSION}

The effect that inquilines phytophagous have over the gallers is still insufficiently discussed in the literature and only superficially understood. Some authors, for example FerNANDES et al. (1987), have suggested the occurrence of strong competitive effect among the phytofagous insects associated with the Anadiplosis sp. gall (Diptera, Cecidomyiidae) in Machaerium aculeatum Raddi (Leguminosae). Hawkins \& Goeden (1982) described the biology of the Tetrastichus cecidobroter and its role in the larvae mortality of a galler cecidomyiid. These authors, however, did not detail or quantify the existing relationship between these species, making it impossible to know the contribution of this chalcidoid wasp in the mortality of that gall former species.

In the studied system it is described in M. lundiana the endogaller wasp species held its special importance as a mortality factor of the M. maricaensis population, surpassing the total rate of mortality caused by all the other wasps species together (including the parasitoid ones). The globular gall (endogall) was then more frequent and abundant than the other two types, and between July/92 and August/93 it had twice as much (44.3\%) abundance of the two other species of wasps (Eulophidae sp. 1 and a platigasterid parasitoid) together (21.7\%) (Fig. 1). The fact that this tetrastichini eulophid was not found in any other M. lundiana gall or of any other plant of the area, suggests an intimate association, possibly obligatory, among these species.

The larvae of the Eulophidae sp. 1, although detected in the modified galls from that original galls, did not developed any structure as endogalls found in the globular modified gall caused by the endogaller eulophid (sp.2). This indicates that the larvae of this eulophid use the gall tissue as food, causing the modification of the original gall shape but without closing the cecidomyiid central chamber. Therefore, probably the $M$. maricaensis larva mortality may be due to the competition through the use and possibly manipulation of the gall tissue or even due to the direct interaction of the modifier larvae with the M. maricaensis larva.

The tissue modification of the M. maricaensis gall by the endogaller eulophid, confers to the latter the role of a effective galler (endogaller), as well as T. cecidobroter in the Asphondylia sp. galls in Atriplex spp. It is evident that, in both cases, there is an alteration of the cell organization of a plant tissue, in spite of the fact that both species make use of the gall tissues and thus initially manipulated already. On the other hand, the eulophid sp.1, that does not produce endogalls in the original gall tissue and does not modify the gall shape and its anatomy so strongly, was just considered as a species that is just a gall modifier.

The mortality caused by the endogaller eulophid is consequently the result of its endogalls growth, resulting in compression of the larval chamber of the galler. The fact that the endogallers compresses the M. maricaensis larva chamber killing it may be considered as a competition for space between two species. But, also have to be considered the possibility of the occurrence of competition for nutrients between the endogaller eulophid larvae and the galler larva. It is reasonable to admit that, due to the development of several eulophid endogalls inside the M. maricaensis gall tissue, the deviation of nutrients to the several microhymenopteran endogalls may occur as they develop themselves, making these nutrients unavailable for the M. maricaensis larva.

The endogall walls are thick and hard, possibly sclerified, resembling those endogalls described by Hawkins \& Goeden (1982), caused by the T. cecidobroter. These authors suggest that this sclerification may be useful to protect the microhymenopteran larvae development against the galler larva interference. This hypothesis is also reasonable in the case of the $M$. maricaensis endogaller and supports the idea of competition between these species.

The food competition among phytophagous species in galls is not very much studied yet. However, Fernandes et al. (1987) suggest the existence of numerous examples of systems where the competition among gallers, inquilines insects and other arthropods may occur, where the asymmetrical competition between inquilines wasp species and a galler Anadiplosis sp. would favor the first ones. The galler species was then considered by the authors a subordinate species in that system.

In the M. lundiana, the subordinate species is also the galler once it frequently dies in the interaction, either by the modifier eulophid or by the endogaller eulophid, and it only survives when few larvae of these wasp species are present in a gall. In this system, the endogaller eulophid was the dominant species, for due to its habit and abundance acts as the main mortality factor on the M. maricaensis.

The relationship between these endogaller species and the M. maricaensis galler is an unusual example of high mortality caused by the phytofagous insect on another one resulting in an effect like that of a parasitoid or predator.

The synchronization of the endogaller populations and the $M$. maricaensis also reveals a kind of interaction that is very similar to the type of parasitoid-host fluctuation. This charac- 
teristic may be better observed between the months of March and August/93 (figure 2). This fact associated with the mortality caused by the endogaller gives this interaction a peculiar characteristic for it is essentially a competitive relationship (for space and nutrients) that, however, has parasitoidism characteristics $(-,+)$ (although it is indirect), not only from the population point of view, but also in the resulting effect for each species involved, (the galler in almost all the cases, dies and the endogaller is benefited by the gall tissue).

Hawkins \& GoEden (1982) reported T. cecidobroter as the first probable case of an obligatory galler microhymenopteran of another galler. This work describe the second case of endogaller habit, possibly obligatory too, being this one the first register of an endogall in the Neotropical region. Nevertheless, observations in other galls in restinga and atlantic rainforest in Brazil indicate that endogall cases similar to the system described here may be frequent.

The life history of the M. maricaensis shows some synchrony with the host plant fenology and very possibly with the climatic conditions of the study area. For this reason the possible diapause of the M. maricaensis may allow the galler to transpose the hot and humid season (spring and summer), in the litter under the host plant and thus in possibly milder and more stable conditions than those found in the same season inside the galls exposed in the plant, besides the fact that it permits the galler insect to adjust its ephemeral adult phase with the available reproductive resources.

The fact that the endogaller microhymenopteran alters the M. maricaensis gall tissue also allow the association of three inquilines insect species of the globular gall that directly feeds themselves with its tissue, what makes the endogaller an heterogeneity factor increasing the richness and the complexity of the insect community associated with the galls.

\section{ACKNOWLEDGEMENTS}

We thank Maria Antonieta Pereira de Azevedo (Museu Nacional, Rio de Janeiro) for her help in microhymenopterous identification and Dra.Graziela Maciel Barroso (Jardim Botânico, Rio de Janeiro) for the plant identification. This study was supported by CNPq and FAPERJ.

\section{REFERENCES}

Briggs, C.J. \& J. Latto. 1996. The window of vulnerability and its effect on relative parasitoid abundance. Ecological Entomology, London, 21: 128-140.

Currie, G.A. 1937. Galls on eucalyptus trees. A new type of association between flies and nematodes. Proceedings of the Linnean Society, N.S.W., 62: 147-174.

Fernandes, G.W.; R.P. Martins \& E. Tameirão-Neto. 1987. Food web relationship involving Anadiplosis sp. galls (Diptera, Cecidomyiidae) on Machaerium aculeatum (Leguminosae). Revista Brasileira de Botânica, São Paulo, 10: 17-23.

GAHAN, A.B.1922. A list of phytophagous Chalcidoidea with descriptions of two new species. Proceedings of the Entomological Society of Washington 24: 33-58.

Gahan, A.B. \& C. Ferrière. 1947. Notes on some gall-inhabiting Chalcidoidea (Hymenoptera). Annals of the Entomological Society of America, Lanham, 40: 271-302.

LaSalle, J. \& M.E. Schauff. 1995. Eulophidae, p. 315-329. In: P.E. Hanson \& I.D. Gauld (Eds). The Hymenoptera of Costa Rica. Oxford, Oxford University Press, 893p.

Hawkins, B.A. \& R.D. Goeden. 1982. Biology of a gall-forming Tetrastichus (Hymenoptera, Eulophidae) associated with gall midges on Saltbush in Southern California. Annals of the Entomological Society of America, Lanham, 75 (4): 444-447.

HAWKINS, B.A. \& R.D. GoEDEN. 1984. Organization of a parasitoid community associated with a complex of galls on Atriplex spp. in southern California. Ecological Entomology, London, 9: 271-292.

Hawkins, B.A. \& R.J. Gagné. 1989. Determinants of assemblage size for the parasitoids of Cecidomyiidae (Diptera). Oecologia, Berlin, 81: 75-88.

MAIA, V.C. 1995. Dois gêneros novos de Cecidomyiidae (Diptera) associados à Myrtaceae, na restinga de Barra de Maricá, Rio de Janeiro, Brasil. Revista Brasileira de Zoologia, Curitiba, 12 (3): 567-574.

Price, P.W. \& K.M. Clancy. 1986. Interactions among three trophic levels: gall size and parasitoid attack. Ecology, Ithaca, 67:1593-1600.

Washburn, J.O. \& H.V. Cornell. 1981. Parasitoids, patches and fenology: their possible role in the local extinction of a cynipid gall wasp population. Ecology, Ithaca, 62 (6): 15971607.

Weis, A.E. \& W.G. Abrahamson. 1985. Potencial selective pressures by parasitoids on plant-herbivore interaction. Ecology, Ithaca, 66 (4): 1261-1269.

Received in 13.II.2003; accepted in 13.VIII.2003. 